\title{
KERAGAMAN HAMA SERANGGA TANAMAN PAPRIKA (Capsicum annum L) DI DATARAN MEDIUM KABUPATEN LOMBOK UTARA
}

\author{
DIVERSITY OF INSECT PEST PLANTS PAPRICA (Capsicum annum L) \\ IN MEDIUM PLANTS, NORTH LOMBOK REGENCY \\ Hairul Anas ${ }^{1}$, Hery Haryanto ${ }^{2}$, Irwan Muthahanas ${ }^{3}$ \\ ${ }^{1,2,3}$ Program Studi Agroekoteknologi Universitas Mataram, Kota Mataram, Indonesia \\ *Email Penulis Korespondensi: khairul28anas@gmail.com
}

\begin{abstract}
Abstrak
Paprika memiliki nama latin Capsicum annum L. adalah tumbuhan penghasil buah yang berasa manis dan sedikit pedas dari suku terong-terongan atau Solanaceae. Budidaya paprika umumnya dilakukan pada dataran tinggi. Namun seiring dengan kebutuhan paprika yang kian hari semakin meningkat, untuk itu budidaya paprika ini dilakukan di dataran medium. Salah satu penyebab menurunya produktivitas tanaman paprika disebabkan oleh hama. Hama jenis serangga yang berpotensi menyebabkan kehilangan hasil pada tanaman paprika diantaranya thrips (Thrips parvispinius), kutu putih (B. tabaci), tungau (Polypahagotarsonemus latus), kutu daun (Myzus persicae) ulat grayak (S. litula), dan lalat bauh (Bactrocera sp.). Tujuan dari penelitian ini adalah untuk mengetahui keragaman hama tanaman Paprika (Capsicum annum L.) di dataran medium Lombok Utara. Percobaan ini mengunakan metode deskriptif dengan tehnik survei secara langsung pada lapangan dan koleksi spesimen. Tehnik survei lapangan digunakan untuk pengambilan sampel dan koleksi spesimen digunakan untuk keperluan identifikasi. Hasil penelitian menunjukan bahwa 8 jenis serangga hama yang ditemukan berasosiasi dengan tanaman Paprika di dataran medium Kabupaten Lombok Utara antara lain Bactrocera dorsalis, Bactrocera umbrosa, A. gossypii, M. persicae, Paracoccus sp., valangga sp., Lacusta sp., S. litula. Nilai indeks keragaman serangga hama menunjukan H' 0.843 yang tergolong rendah, hal tersebut menunjukan bahwa produktifitas dan kondisi ekosistem cukup rendah. Serangga hama dengan populasi dan kelimpahan tertinggi yaitu Bactrocera dorsalis dengan kelimpahan sebesar $71.56 \%$.
\end{abstract}

Kata Kunci : hama paprika, keragaman dan kelimpahan.

\begin{abstract}
Paprika has the Latin name Capsicum annum L. is a plant a sweet and slightly spicy fruit from the eggplant tribe or Solanaceae. Cultivation of paprika is generally carried out in the highlands. However along with the need for paprika which is increasing day by day, for that Paprika cultivation is carried out in medium plains. One of the causes reduced productivity of paprika is caused by pests. Type pests nsects that have the potential to cause yield loss in paprika including thrips (Thrips parvispinius), mealybugs (B. tabaci), mites (Polypahagotarsonemus latus), aphids (Myzus persicae) armyworms (Spodoptera litula), and bauhaus (Bactrocera sp.). The purpose of this study is to determine the diversity of pests of Paprika (Capsicum annum L.) in the medium plains of North Lombok. This experiment uses the method descriptive with direct survey techniques in the field and collections specimen. Field survey techniques were used for sampling and specimen collections are used for identification purposes. Research result shows that 8 types of insect pests were found to be associated with Paprika plants in the medium plains of North Lombok Regency, among others Bactrocera dorsalis, Bactrocera umbrosa, A. gossypii, M. persicae, Paracoccus sp., Valangga sp., Lacusta sp., S. litula. Pest insect diversity index value shows $\mathrm{H}$ ' 0.843 which is classified as low, it shows that productivity and ecosystem conditions are quite low. Insect pests with The highest population and abundance is Bactrocera dorsalis with abundance $71.56 \%$.
\end{abstract}

Keywords : paprika pests, diversity and abundance.

Anas, H., Haryanto, H., dan Muthahanas, I. 


\section{PENDAHULUAN}

Paprika memiliki nama latin Capsicum annum $L$. adalah tumbuhan penghasil buah yang berasa manis dan sedikit pedas dari suku terong-terongan atau Solanaceae. Tanaman ini berasal dari dataran Amerika Selatan seperti Meksiko, Peru dan Bolivia dan sekarang ini paprika sudah tersebar luas keberbagai penjuru dunia dan banyak dibudidayakan hampir semua wilayah. Di Indonesia tanaman paprika mulai dibudidyakan sejak tahun 1990-an. Paprika merupakan sayuran yang banyak memiliki manfaat dan sangat baik bagi kesehatan manusia karena mengandung vitamin $\mathrm{C}$. Selain mengandung vitamin $\mathrm{C}$ paprika juga mengandung senyawa-senyawa fitokimia yang terdiri dari fenolik, flavonoid, dan karetenoid. Senyawa ini berfungsi sebagai antioksidan sehingga paprika dipercaya dapat menyembuhkan beberapa penyakit (Kelley and Boyhan, 2009).

Produksi buah paprika, selain untuk memenuhi kebutuhan pasar dalam negeri (hotel berbintang, pasar swalayan, dan rumah makan internasional, serta pasar tradisonal) juga untuk memenuhi kebutahan pasar ekspor. Produksi buah paprika di Indonesia dari tahun 2013-2017 mengalami fluktuasi yaitu sebanyak 7028 ton, 5658 ton, 5256 ton, dan 7394 ton. Produksi paprika pada tahun 2017 paling banyak terdapat di pulau Jawa Barat sebanyak 5104 ton dan Jawa Timur sebanyak 2038 ton (BPS, 2017). Paprika masih belum cukup popular untuk dipakai sebagai salah satu bahan masakan sayuran khas Indonesia, namun peluang untuk mengembangkan bisnis di komoditi ini terbuka lebar. Paprika memiliki nilai jual yang bagus, permintaan pasar akan sayuran ini terus meningkat, terutama permintaan dari restoran dan hotel berkembang di Bali (Mila, 2016). Budidaya paprika umumnya dilakukan pada dataran tinggi. Namun seiring dengan kebutuhan paprika yang kian hari semakin meningkat, untuk itu budidaya paprika ini dilakukan di dataran medium.

Menurunya produktivitas tanaman paprika disebabkan oleh dua kendala yaitu abiotik dan biotik, pada abiotik banyak disebabkan oleh ketersediaan hara pada tanaman, semantara kendala biotik meliputi gangguan yang disebabkan oleh organisme pengganggu tanaman (OPT), yang meliputi gulma, penyakit dan hama. Kelompok serangga merupakan hama yang mendominasi pada tanaman paprika. Menurut Harno (2012), Hama jenis serangga yang berpotensi menyebabkan kehilangan hasil pada tanaman paprika, diantaranya yaitu thrips (Thrips parvispinius), kutu putih (B. tabaci), tungau (Polypahagotarsonemus latus), kutu daun (Myzus persicae), ulat grayak (Spodoptera litula), dan lalat bauh (Bactrocera sp.).

Berdasarkan uraian diatas untuk itu perlu adanya penelitian mengenai budidaya paprika di dataran medium. Sehingga penelitian ini dilakukan untuk mengetahui Keragaman Hama Serangga Pada Tanaman Paprika (Capsicum annum L.) di Dataran Medium Kabupaten Lombok Utara.

Penelitian ini bertujuan untuk: mengetahui keragaman hama tanaman Paprika (Capsicum annum L.) di dataran medium Lombok Utara. Sedangkan Kegunaan Penelitian ini diharapkan dapat menjadi sumber informasi terkait dengan keragaman hama tanaman paprika (Capsicum annum L.) di dataran medium Lombok Utara dan sebagai salah satu pertimbangan konsep Pengendalian Hama Terpadu (PHT) yang dapat digunakan dalam upaya pengendalian.

Anas, H., Haryanto, H., dan Muthahanas, I. 


\section{METODE PENELITIAN}

\section{Tempat dan Waktu Percobaan}

Penelitian ini di laksanakan pada lahan milik petani di wilayah Pendua, Kecamatan Kayangan, Kabupaten Lombok Utara dan di Laboratorium Proteksi Tanaman untuk melakukan indentifikasi hama pada tanaman paprika. Penelitian ini dilaksanakan mulai bulan Agustus sampai November 2020.

\section{Bahan dan Alat Percobaan}

Bahan yang di gunakan pada penelitian ini adalah tanaman Paprika, metil eugenol (Petrogenol), alakohol $70 \%$, dan detergen. Sedangkan alat yang akan di gunakan pada penelitian ini adalah perangkap sex feromon, perangkap yellow pan, perangkap pitfall trap, wadah spesimen, cawan petri, pinset, hand counter, gunting, kaca pembesar, mikroskop, alat tulis dan alat dokumentasi.

\section{Racangan Percobaan}

Percobaan ini mengunakan metode deskriptif dengan tehnik survei secara langsung pada lapangan dan koleksi spesimen. Tehnik survei lapangan digunakan untuk pengambilan sampel dan koleksi spesimen digunakan untuk keperluan identifikasi.

\section{Pelaksanaan Percobaan}

\section{Penentuan Lokasi Pengamatan}

Observasi lokasi penelitian dilaksanakan pada bulan Agustus 2020 bertujuan untuk menentukan daerah yang akan diamati. Lokasi tempat pengambilan sampel di lakukan di lahan sawah milik petani di dataran medium Pendua Kacamatan Kayangan Lombok Utara. Lokasi pengambilan sampel dibagi menjadi 3 bedengan dengan jarak tanam $60 \times 60 \mathrm{~cm}$ per tanaman. Pada setiap bedengan terdiri dari 3 jenis perangkap yang berbeda dan diulang sebanyak 2 kali, sehingga pada satu bedengan terdiri 6 perangkap dan keseluruhan perangkap yang dipasang sejumlah 18 perangkap. Jenis perangkap yang dipasang yaitu sex feromon, yellow pan, dan pitfall trap.

\section{Parameter Pengmatan}

Parameter yang diamati dalam percobaan ini adalah menghitung populasi hama, keragaman hama dan intensitas kerusakan hama yang menyerang tanaman. Parameter yang diamati pada populasi hama berupa (telur, larva/nimfa, dan imago) dan parameter keragaman hama ialah jumlah hama yang tertangkap.

\section{Cara Pengambilan Sampel}

Pengamatan dimulai dari 2 minggu setelah tanam (mst), dengan interval satu minggu sekali. Pengamatan populasi hama dilakukan dengan melihat secara langsung dan tidak langsung (pada perangkap yang dipasang). Pengamatan keragaman hama yaitu menjumlahkan jenis hama yang di dapatkan. Kemudian serangga hama yang di dapatkan dikoleksi pada botol yang berisikan alkohol $70 \%$.

\section{Identifikasi Hasil Koleksi}

Serangga-serangga yang telah dikoleksi di bawah ke Laboratorium Proteksi Tanaman untuk dilihat mengunakan mikroskop dan dicocokan dengan mengunakan buku kunci determinasi serangga (Kanisius, 1991) dan jurnal-jurnal lain, Untuk mengetahui jenis-jenis serangga yang bersifat sebagai hama tanaman paprika.

\section{Analisis Data}

Parameter yang diamati dalam percobaan ini adalah populasi hama yang tertangkap dan mengitung keragaman serangga yang terperangkap.

Anas, H., Haryanto, H., dan Muthahanas, I. 


\section{a. Populasi}

Populasi dihitung dengan menjumlahkan langsung hama yang tertangkap baik secara langsung maupun tidak langsung (pada perangkap) selama melakukan penelitian.

b. Keragaman

Indeks Shannon-Wiener, digunakan untuk mengetahui keanekaragaman spesies pada setiap habitat, dengan rumus:

$$
\mathrm{H}^{\prime}=-\quad \Sigma p i \ln p i, \rightarrow p i=\frac{n i}{N}
$$

Keterangan:

$\mathrm{H}^{\prime}=$ Indeks Shannon-Wiener

ni = Jumlah individu untuk spesies yang diamati

$\mathrm{N}=$ Jumlah total individuJika $\mathrm{H}^{\prime}<1$, maka keragaman rendah. Selanjutnya apabila $\mathrm{H}^{\prime}=1$ dan $\mathrm{H}^{\prime}<3$ maka keanekaragaman sedang dan apabila nilai $\mathrm{H}^{\prime}>3$ maka keanekaragamannya tinggi (Agustinawati et al., 2016).

Data yang sudah diperoleh kemudian ditabulasikan untuk menghitung keragaman, kelimpahan dan Intensitas kerusakan. Data rerata populasi dianalisis dengan menggunakan analisis statistika berupa standar deviasi untuk menentukan sebaran data rerata populasi dan analisis regresi korelasi antara kepadatan populasi dan intensitas kerusakan. Data keragaman, kelimpahan, intensitas dan rerata populasi disajikan dalam bentuk tabel, grafik dan diagram batang.

\section{HASIL DAN PEMBAHASAN}

Berdasarkan hasil identifikasi terdapat 8 jenis serangga hama yang ditemukan berasosiasi dengan tanaman Paprika di datraran medium Kabupaten Lombok Utara antara lain Bactrocera dorsalis, Bactrocera umbrosa, A. gossypii, M. persicae, Paracoccus sp., valangga sp., Lacusta sp., S. litula, seperti yang tersajikan dalam tabel 1.

Tabel 1. Keragaman dan Kelimpahan Serangga Hama

\begin{tabular}{lcccccc}
\hline \multicolumn{1}{c}{ Jenis } & Total & PI & LN PI & PI LNPI & H' $^{\prime}$ & Kelimpahan (\%) \\
\hline B. dorsalis & 5667 & 0.716 & -0.335 & -0.239 & 0.239 & 71.56 \\
B. umbrosa & 200 & 0.025 & -3.679 & -0.093 & 0.093 & 2.53 \\
A. gossypii & 463 & 0.058 & -2.839 & -0.166 & 0.166 & 5.85 \\
M. persicae & 1561 & 0.197 & -1.624 & -0.320 & 0.320 & 19.71 \\
Paracoccus sp. & 8 & 0.001 & -6.898 & -0.007 & 0.007 & 0.10 \\
valangga sp. & 8 & 0.001 & -6.898 & -0.007 & 0.007 & 0.10 \\
Lacusta sp. & 4 & 0.001 & -7.591 & -0.004 & 0.004 & 0.05 \\
S. litula & 8 & 0.001 & -6.898 & -0.007 & 0.007 & 0.10 \\
\hline Total & 7919 & & & & 0.843 & 100 \\
\hline
\end{tabular}

Dari hasil analisis indeks keragaman Shannon (H') yang ditunjukan pada tabel 1, didapatkan nilai indeks keragaman serangga hama pada tanaman paprika di dataran medium Kabupaten Lombok Utara adalah H' 0.843 yang tergolong rendah, hal tersebut menunjukan bahwa produktifitas dan kondisi ekosistem cukup rendah. Nilai indeks keragaman jenis ini akan dapat berubah seiring dengan perubahan komposisi jenis dan sebaran atau kelimpahan masing-masing jenis. Perubahan ini tentunya akan sangat bergantung pada perubahan kondisi habitat serangga tersebut (Ariani, 2013).

Anas, H., Haryanto, H., dan Muthahanas, I. 


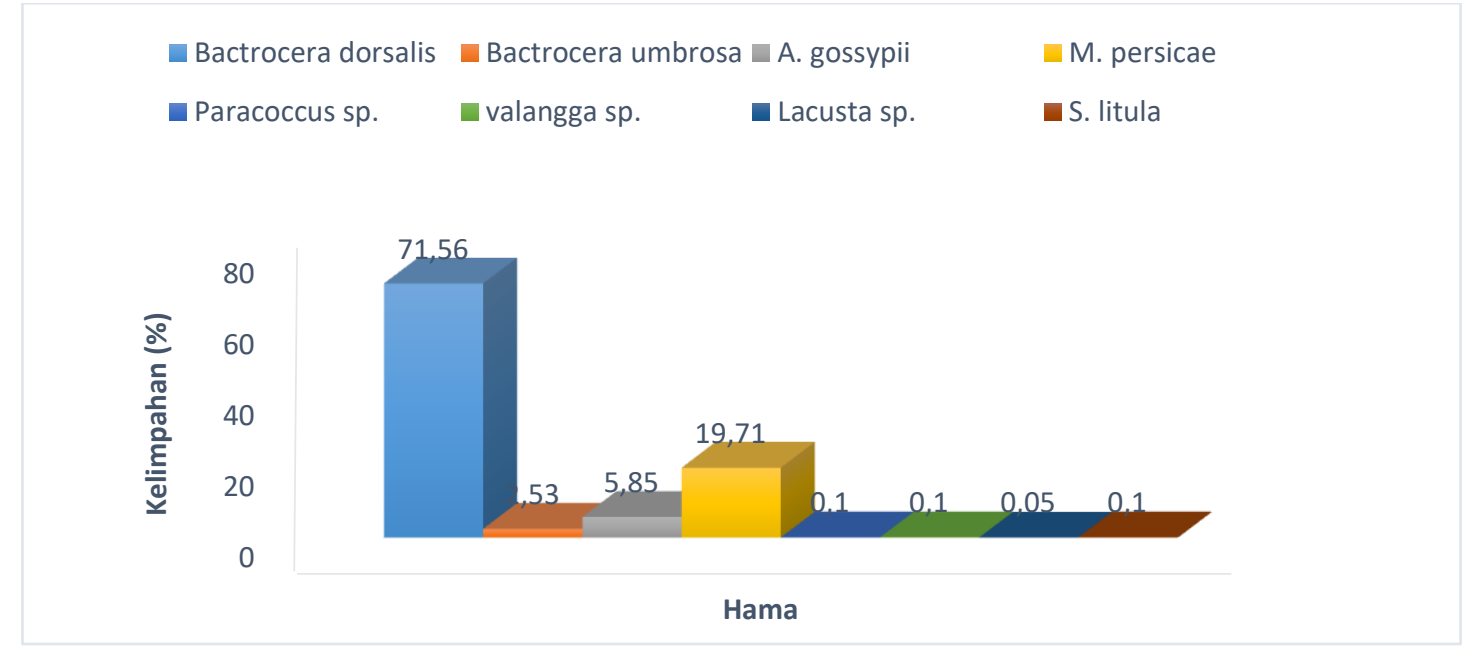

Gambar 1. Kelimpahan serangga hama tanaman paprika

Gambar 1. Menunjukan bahwa kelimpahan hama yang paling tinggi adalah Bactrocera dorsalis sebesar 71,56\%, sedangkan kelimpahan paling rendah yaitu Lucusta sp. sebesar $0.05 \%$. Keragaman dan populsi serangga hama di alam tidak konstan atau berfluktuasi. Tinggi rendahnya keragaman serangga hama tergantung pada faktor-faktor yang mempengaruhinya, diantarnya adalah faktor makanan, suhu, curah hujan dan kelembaban (Muchlis, 2019).

\section{Karakteristik Morfologi Serangga Hama dan Gejala Serangan Pada Tanaman Paprika di Dataran Medium Lombok Utara}

Berdasarkan hasil identifikasi terdapat 8 jenis serangga hama yang ditemukan pada budidaya tanaman paprika di dataran medium Lombok Utara yaitu Bactrocera Umbrosa, Bactrocera dorsalis, A. gossypii, M. peraicae, paracoccus sp., valangga sp., lacusta sp., S. litua.

\section{Lalat Buah}
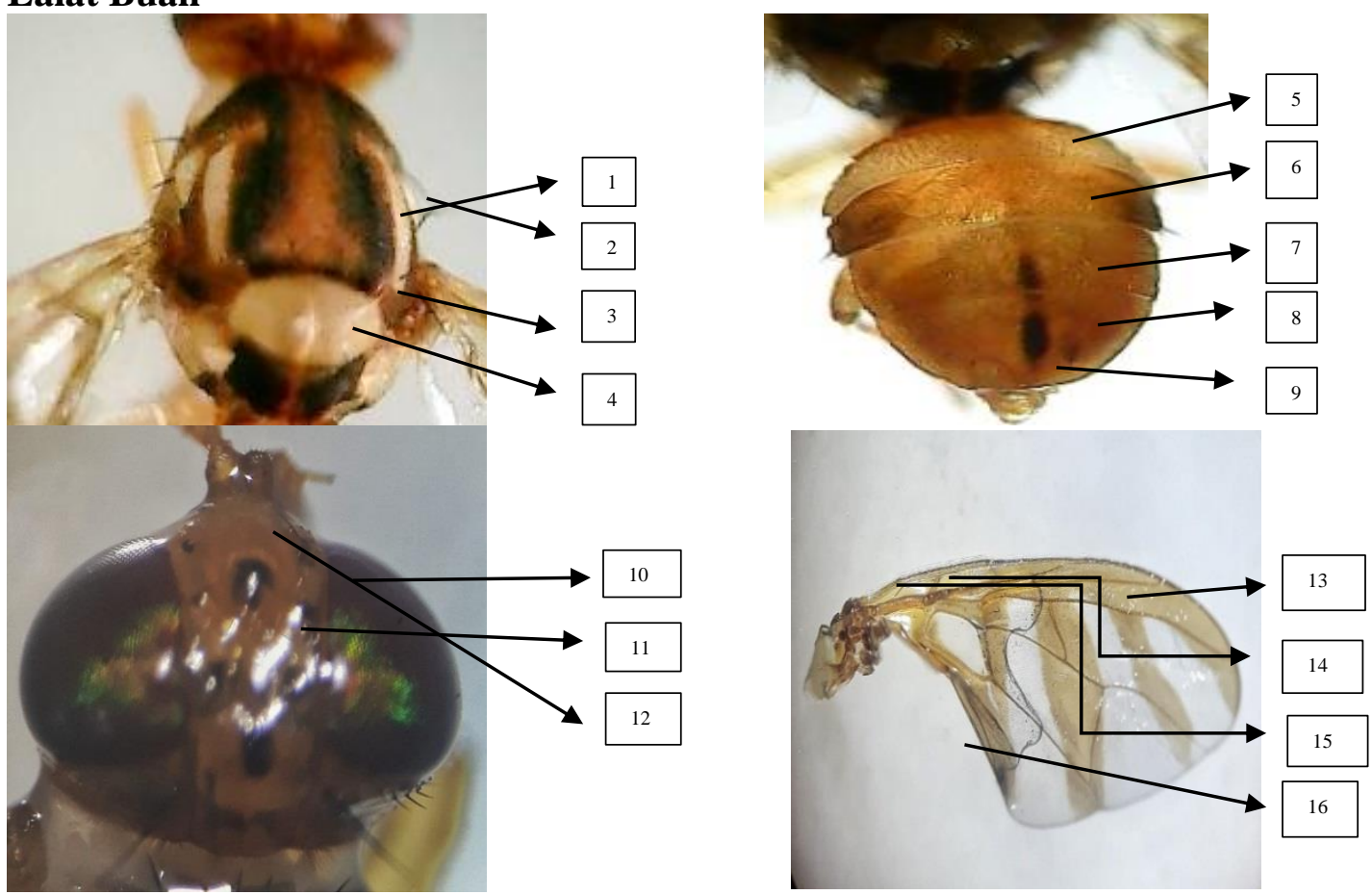

Gambar 2. Spesies Bactrocera Umbrosa

Anas, H., Haryanto, H., dan Muthahanas, I. 
Keterangan:

(1) Pita band (2) Rambut Supra alar (3) Rambut Presscullella (4) Bagian berbentuk segi tiga skulelum (5) Tergit/segmen I (6) Tergit/segmen II (7) Tergit/segmen IV (8) Tergit/segmen VI (9) Tergit/segmen VII (10) Mata (11) Ronga antenna (12) Facial Spot (13) Pembuluh Sayap (14) Costal band (15) Costal band (16) Anal lobe.

Ciri yang mudah dikenal dari Bactrocera umbrosa adalah tubuhnya memiliki warna kecoklatan dan ukuran tubuhnya sedikit besar. Spot hitam pada muka, mudah dikenal dengan gambaran tiga pita melintang pada sayapnya, skutum berwarnah hitam dengan strip kuning di kedua sisi lateral, rambut terdapat di anterior supra alar dan prescutella acrosticahal dan dua rambut pada scutella, kaki berwarna kuning, bagian basal dan posterior berbulu (Siwi, 2004).
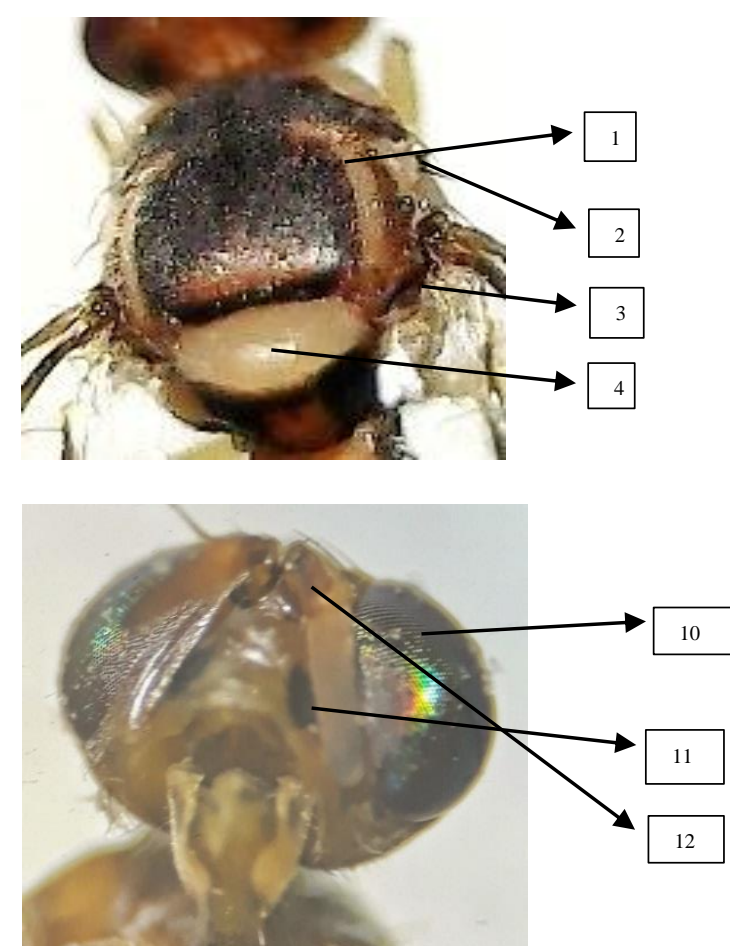
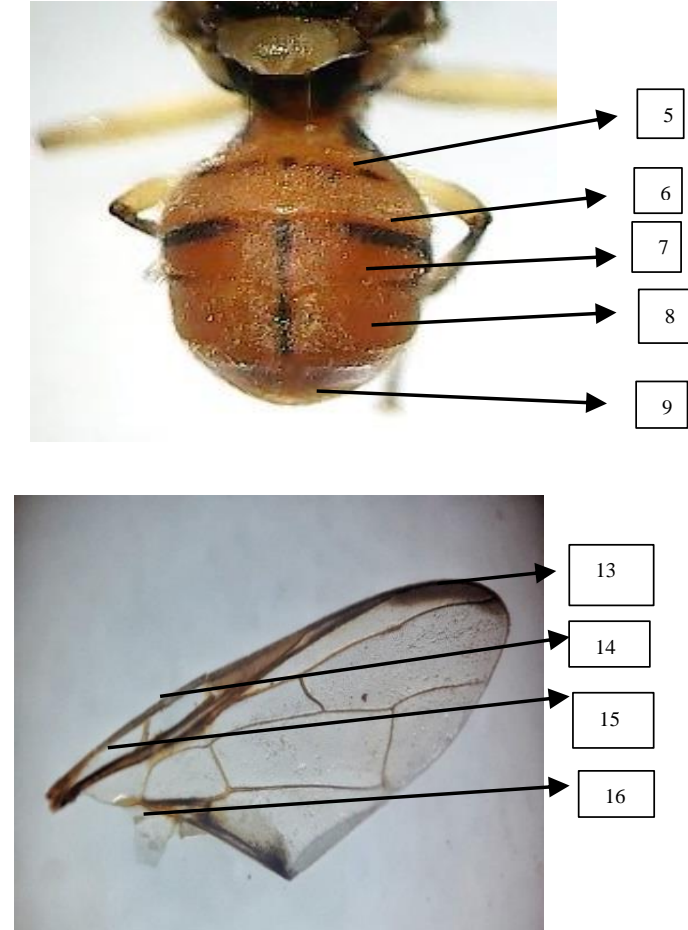

Gambar 3. Spesies Bactrocera dorsalis

Keterangan:

(1) Pita band (2) Rambut Supra alar (3) Rambut Presscullella (4) Bagian berbentuk segi tiga skulelum (5) Tergit/segmen I (6) Tergit/segmen II (7) Tergit/segmen IV (8) Tergit/segmen VI (9) Tergit/segmen VII (10) Mata (11) Ronga antenna (12) Facial Spot (13) Pembuluh Sayap (14) Costal band (15) Costal band (16) Anal lobe.

Abdomen sebagian besar berwarna merah pucat (coklat), terdapat pita hitam melintang pada tergit-2 dan tergit-3, pita hitam sempit longitudinal membelah ditengahtengah tergit 3-5. Pada sayap hanya mempunyai pita hitam pada garis costa dan garisanal, tidak mempunyai noda-noda pada vena melintang. pada toraks skum berwarna hitam, mesonotum (torak tengah) hitam, pita lateral kuning pada mesonotum memanjang ke dekat rambut supra akar, 2 pasang rambut pada frontomorbital bagian dalam, dua rambut pada skutulem (Siwi, 2004).

Gejala awal serangan lalat buah ditunjukan oleh adanya noda hitam berukuran kecil. Bintik-bintik kecil yang berwarna hitam tersebut merupakan bekas tusukan ovipositor. Larva yang baru menetes langsung memakan daging buah, akibat dari aktivitas larva ini menyebabkan bagian buah yang ada disekitarnya menjadi bercak luas dan basah yang bertambah selain itu, kulit buah bertambah menjadi tipis. Selanjutnya

Anas, H., Haryanto, H., dan Muthahanas, I. 
larva akan memakan daging buah sehingga buah menjadi busuk dan gugur sebelum waktunya (Kusnaedi, 1991).

\section{Kutu-kutuan}

Hasil identifikasi menunjukan bahwa ada 2 jenis kutu daun dan 1 jenis kutu putih yang ditemukan berasosiasi dengan tanaman paprika di dataran medium Lombok Utara yaitu A. gossypii, M. persicae dan kutu putih yaitu Paracoccus $s p$.

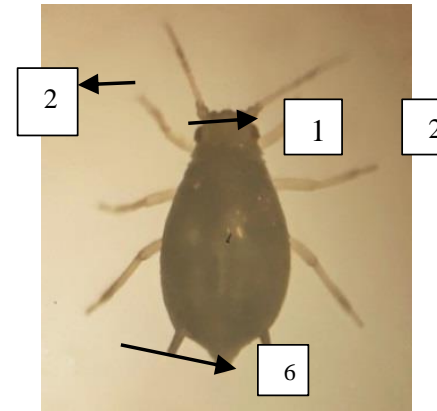

(a)

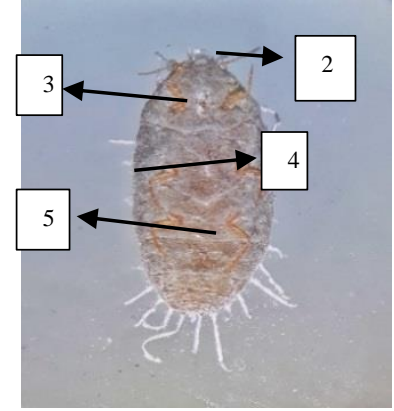

(c)

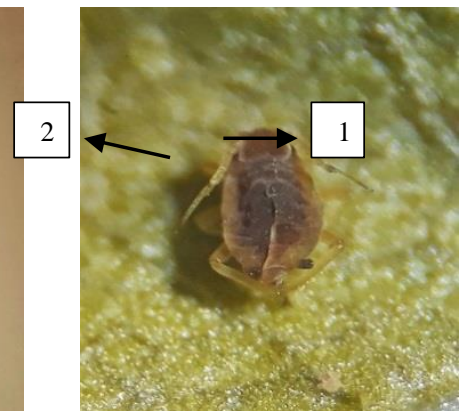

(b)

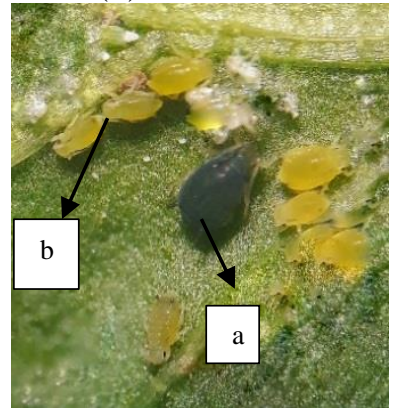

(d)

Gambar 4. (a) A. gossyppi (b) M.persicae (c) Paracoccus sp. (d) Daun yang terserang kutu daun. (1) Kepala (2) Antena (3) Tungkai depan (4) Tungkai tenggah (5) Tungkai belakang (6) Comicle.

Ciri-ciri A. gossypii menurut Susetyo (2017) yaitu Bentuk kepala dan antena kelihatan agak rata, ukuran dan bentuk badan agak bulat besar jika dibandingkan dengan kelas-kelas yang lainnya, panjang antena agak pendek dibandingkan dengan $M$ .persicae, comicle bentuknya agak melebar, warna kulit bisa berubah-ubah sesuai dengan cuaca yaitu hitam, hijau. Menurut Nechiyana dkk (2011) A. gossypii menyebabkan kerusakan dengan cara menusuk jaringan dan menghisap cairan sel daun yang mengakibatkan daun tumbuh tidak normal.

Karaktersitik suatu hama $M$. persicae berdasarkan hasil identifiksi menunjukan bahwa ukuran $M$. persicae lebih kecil dari ukuran A. gossypii dan bentuk badanya agak ramping dibandingkan A. gossypii. Hal ini sesuai dengan penelitian Susetyo (2017) bahwa karakteristik dari $M$. persicae yaitu berukuran kecil Antara 0.6-3 mm dan lebih ramping dibandingkan A. gossypii. Tubuhnya hijau atau hijau pucat, kadang-kadang jinga atau kuning. Bentuk kepala berlekuk membentuk huruf $\mathrm{W}$, panjang antenna lebih panjang dari A. gossypii. Gejala awal berupa bercak kering pada daun dan menyebabkan tanaman mongering, keriput, tumbuh kerdil, warna daun kekuningan, layu dan mati. Virus yang ditularkannya Potato yellow virus (PYV), Potato Mosaic Virus (PMV) dan virus lainya.

Hasil identifikasi Paracoccus sp. yang ditemukan pada tanaman paprika di dataran medium Lombok Utara yaitu menunjukkan adanya kesamaan ciri morfologi dengan hasil penelitian Williams and Granara de Willink (1992) bahwa tubuh Paracoccus sp.

Anas, H., Haryanto, H., dan Muthahanas, I. 
berbentuk oval dengan embelan seperti rambut-rambut berwarna putih dengan ukuran yang pendek sekitar $1 / 4$ dari panjang tubuh. Betina dewasa memiliki tubuh berwarna kuning, dan memiliki antena delapan ruas. Kutu putih Paracoccus sp. merusak dengan cara mengisap cairan. Semua bagian tanaman bisa diserangnya, Serangan pada pucuk menyebabkan daun kerdil dan keriput seperti terbakar.

\section{Ulat Grayak}

Hasil identifikasi menunjukan bahwa jenis ulat grayak yang didapatkan pada tanaman paprika di dataran medium Lombok Utara yaitu Spodoptera litura dan berikut gambarnya.

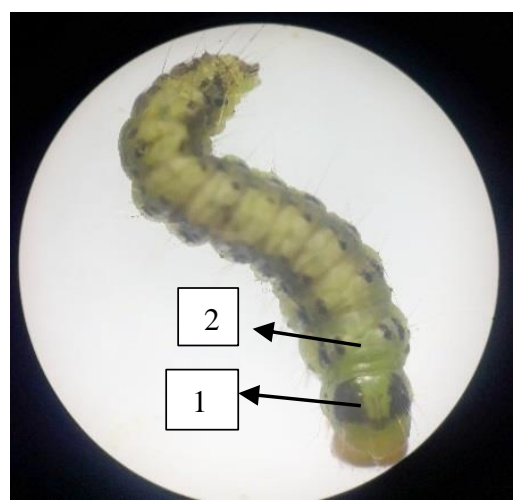

Gambar 5. S. litura.

Ket: (1) Kalung bulan sabit, (2) Garis hitam sepanjang tubuh.

Karakteristik hama S.lutura berdasarkan hasil identifikasi yaitu Larva berwarna hijau, terdapat bintik-bintik sepanjang tubuh, memiliki kalung bulan sabit berwarna hitam. Hal ini sesuai dengan pendapat Erwin (2000) adalah larva memiliki kalung bulan sabit berwarna hitam pada segmen abdomen keempat dan kesepuluh. Pada sisi lateral dorsal terdapt garis kuning. Gejala kerusakan yaitu kerusakan daun yang diakibatkan larva merusak daun dan meninggalkan sisa-sisa bagian atas transparan dan tinggal tulang-tulang daun saja. Pada serangan berat menyebabkan gundulnya tanaman (Sudarmo, 1992).

\section{Belalang}

Hasil identifikasi menunjukan bahwa jenis belalang yang ditemukan yait belalang kayu Valanga sp. dan Locusta sp. sebagai berikut:

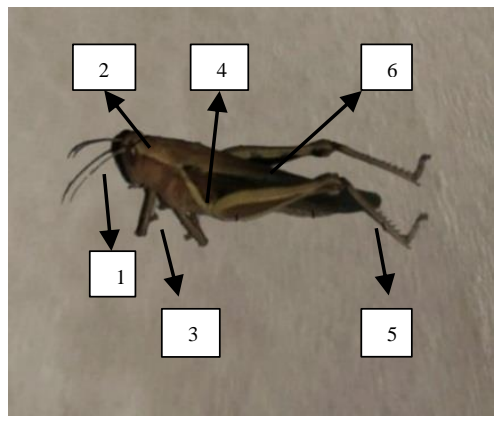

(a)

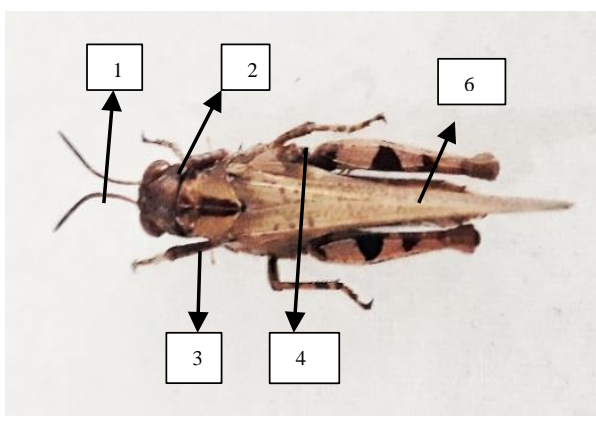

(b)

Gambar 6. (a) Locusta sp. (b) Valannga sp. (1) Antena, (2) Mata majemuk, (3) Tungkai depan, (4) Tungkai tenggah, (5) Femur tangkai belakang (6) sayap.

Hasil pengamatan terhadap karakteristik morfologi Valanga sp. dan Lacusta sp. menunjukkan adanya kesamaan ciri morfologi dengan kunci identifikasi Borror (1992)

Anas, H., Haryanto, H., dan Muthahanas, I. 
pada tingkat famili yaitu, memiliki tungkai belakang yang lebih besar dibandingkan dengan tungkai depan, tarsi belakang 3 ruas, tarsi depan dan tengah 2 atau 3 ruas, alat perteluran (ovipositor) pendek, sungut lebih pendek dari ukuran tubuh dan berbentuk filiform, jarang lebih dari setengah panjang tubuh, memiliki organ pendengaran (tympana) pada sisi-sisi ruas abdomen pertama. Karakteristik morfologi yang khas pada belalang kayu (Valanga sp.) berdasarkan hasil identifikasi adalah femur belakang memiliki sepasang titik hitam dan tibia belakang berwarna merah sampai keunguan. Apabila belalang ini terbang terlihat sayap belakang berwarna merah.

Tingkat kerusakannya tergantung dari jumlah populasi serta tanaman yang diserang. Serangga ini dapat hidup di berbagai lingkungan diantaranya di lahan pertanian, semak, di lingkungan tempat tinggal, di lahan perkebunan dan lain sebagainya. Mereka juga dapat berpindah tempat dari satu tempat ke tempat yang lain untuk mencari makanan bahkan terkadang tempat yang mereka datangi dapat rusak karena jumlahnya yang sangat banyak (Falahuddin et al., 2015).

\section{KESIMPULAN DAN SARAN}

\section{Kesimpulan}

Berdasarkan hasil penelitian dan analisis yang telah dilakukan, maka dapat ditarik kesimpulan sebagai berikut:

1. Terdapat 8 jenis serangga hama yang berasosiasi dengan tanaman paprika di dataran medium Kabupaten Lombok Utara antara lain yaitu Bactrocera dorsalis, Bactrocera umbrosa, Aphis gossypii, Myzus persicae, Paracoccus sp., valangga sp., Lacusta sp., dan Spodoptera. litula.

2. Nilai indeks keragaman serangga hama menunjukan $\mathrm{H}^{\prime} 0.843$ yang tergolong rendah, hal tersebut menunjukan bahwa produktifitas dan kondisi ekosistem cukup rendah.

3. Serangga hama dengan populasi dan kelimpahan tertinggi yaitu Bactrocera dorsalis dengan kelimpahan sebesar $71.56 \%$.

\section{Saran}

Disarankan untuk melakukan pemantauan secara terus menerus terhadap hamanya agar diperoleh pola perkembangan masing-masing dari jenis hama untuk menentukan tindakan pengendalian yang tepat.

\section{DAFTAR PUSTAKA}

Ariani L., Artayasa I. P., dan Ilhamdi H.M.L. 2013. Keragaman dan Distribusi Jenis Kupu-Kupu (Lepidoptera) di Kawasan Hutan Taman Wisata Alam Suranadi sebagai Media Pembelajaran Biologi. Di dalam Prosiding Seminar Nasional Penelitian, Pembelajaran Sains, dan Implementasi Kurikulum 2013. Mataram, 7 Desember 2013. Hal. 160-167.

Badan Pusat Statistik. 2017. Produksi Tanaman Sayuran Paprika. https://www.bps.go.id/resultTab. [12 Mei 2019].

Falahuddin I., Mareta D.E, Rahayu I.A.P. 2015. Diversitas Serangga Ordo Orthoptera Pada Lahan Gambut Di Kecamatan Lalan Kabupaten Musi Banyuasin. Bioilmi Vol. 1 No. 1 Edisi Agustus 2015.

Harno. 2012. Hama dan Penyakit Pada Budidaya Tanaman Cabai Paprikai. http://harno_net.blogspot.com/2012/05/hama_penyakit_pada_budidaya_cabaipa

Anas, H., Haryanto, H., dan Muthahanas, I. 
prika. html.m=1.

Kelley,W.T. \& Boyhan, G. 2009. Comercial Peper Production Handbook. Universitas of Georgia: 56.

Kusnaedi. 1991. Pengendalian Hama Tampa Pestisida. Jakarta. Tanindo Press.

Mila, dkk. 2016. Pengaruh Pemberian Pupuk Mikoriza Terhadap Pertumbuhan dan Hasil Tanaman Paprika. Agroekoteknologi Fakultas Pertanian Universitas Mahasaraswati Denpasar. Bali.

Muchlis. 2019. Serangga Hama Penting Pada Pusat Pengembangan Tebu di Kabupaten Doтрu. [Skripsi]. Fakultas Pertanian, Universitas Mataram. Mataram. Indonesia.

Nechiyana, A. Sutikno, D. Salbiah. 2011. Pengunaan Ekstrak Daun Pepaya Untuk Mengendalikan Hama Kutu Daun pada Tanaman Cabai. [Skripsi]. Fakultas Pertanian Universitas Riau. Hal 2.

Siwi, S.S., Purnama, H. 2004. Taksonomi dan Bioekologi Lalat Buah Penting Bactrocera spp. (Diptera: Tephiritidae di Indonesia. Balai Besar Penelitian dan Pengembangan bioteknologo dan Sumberdaya Genetik Pertanian.

Sudarmo, S. 1992. Tembakau. Yogyakarta: Penerbit Kanisius.

Williams, D.J., Granara de Willink MC. 1992. Mealybugs of Central and South America. Wallingford Oxon, United Kigdom: CABI.

Anas, H., Haryanto, H., dan Muthahanas, I. 